\title{
Downregulation of Fasting-Induced cAMP Response Element- Mediated Gene Induction by Leptin in Neuropeptide Y Neurons of the Arcuate Nucleus
}

\author{
Masami Shimizu-Albergine, Danielle L. Ippolito, and Joseph A. Beavo \\ Department of Pharmacology, School of Medicine, University of Washington, Seattle, Washington 98195
}

\begin{abstract}
States of increased metabolic demand such as fasting modulate hypothalamic neuropeptide gene expression and decrease circulating leptin levels. This study tested the hypotheses that fasting stimulates gene induction mediated by cAMP response element (CRE)-dependent increases in gene transcription and that fasting-induced decreases in leptin can regulate this CREmediated gene induction. Using C57BL/6J mice transgenic for a CRE-lacZ construct, an immunocytochemical study showed that fasting activated reporter gene expression in the hypothalamic arcuate nucleus (Arc) in a small subset of neurons and increased phosphorylation of CRE binding protein. The increase of $\beta$-galactosidase expression caused by fasting was inhibited by a protein kinase $A$ inhibitor, $\mathrm{Rp}-8-\mathrm{Br}$-cAMPS, when the compound was microinjected into the medial basal hypothalamus, and enhanced by intraperitoneal injection of selective phosphodiesterase inhibitors. In situ hybridization studies showed that neuropeptide Y (NPY) mRNA levels increased in
\end{abstract}

the Arc during fasting, whereas proopiomelanocortin (POMC) mRNA levels decreased. Double labeling of mRNA and $\beta$-galactosidase immunoreactivity in the fasted brain indicated that the subpopulation of the neurons expressing $\beta$-galactosidase all produced NPY but not POMC. To study the possible involvement of decreased circulating leptin during starvation on CRE-mediated gene induction, leptin was administered intraperitoneally to fasted mice. Leptin significantly attenuated both $\beta$-galactosidase expression and NPY gene expression stimulated by fasting, suggesting that leptin inhibits fasting-stimulated NPY gene expression at least in part through downregulation of CRE-mediated gene induction in the Arc. Leptin-induced modification of CRE-mediated gene induction in the Arc may play an essential role in the central regulation of feeding behavior and energy expenditure.

Key words: arcuate nucleus; CAMP; CRE; CREB; leptin; NPY; PKA; PDE inhibitor; POMC
During starvation, expression of various hypothalamic neuronal genes is regulated to change behavioral, hormonal, and metabolic responses leading to a state of positive energy balance. Fasting has been shown to increase the expression of the orexigenic peptide neuropeptide Y (NPY) and decrease the expression of the anorexigenic peptide proopiomelanocortin (POMC) in the arcuate nucleus (Arc) (Kalra et al., 1991; Bergendahl et al., 1992; Kim et al., 1996). The molecular mechanisms of cellular processing required to regulate gene expression during fasting, however, are not understood. A role for cAMP response element (CRE)-mediated gene induction in response to starvation was suggested by a recent study showing that $48 \mathrm{hr}$ of fasting in rats increased CRE binding activity in hypothalamic nuclear extracts (Sheriff et al., 1997). cAMP-dependent protein kinase A (PKA) plays a major role in CRE-mediated gene induction (Habener et al., 1995). Interestingly, central injection of a cAMP analog has been reported to increase NPY protein levels in the Arc (Akabayashi et al., 1994). Several in vitro studies have demonstrated that NPY gene expression is activated by treatment with forskolin

\footnotetext{
Received July 17, 2000; revised Oct. 6, 2000; accepted Nov. 30, 2000.

This study was supported by National Institutes of Health Grant DK 21723. We thank Drs. S. Impey and D. R. Storm, Department of Pharmacology, University of Washington, for providing the CRE-lacZ transgenic mice, and Dr. R. A. Steiner, Departments of Obstetrics and Gynecology, University of Washington, for reviewing this manuscript. We also thank Cari Ostenson for technical assistance.

Correspondence should be addressed to Joseph A. Beavo, Department of Pharmacology, Box 357280, University of Washington, School of Medicine, Seattle, WA 98195. E-mail: beavo@u.washington.edu.

Copyright (C) 2001 Society for Neuroscience 0270-6474/01/211238-09\$15.00/0
}

or cAMP analogs (Higuchi at al., 1988; Magni and Barnea, 1992). Therefore, it is conceivable that the CRE-mediated gene induction modulated by PKA may be involved in NPY gene induction in the hypothalamus during starvation. To test this hypothesis, we used mice transgenic for a CRE-reporter gene (lacZ) construct developed by Impey et al. (1996). Using these transgenic mice, we found that fasting stimulated CREmediated gene induction in NPY-containing neurons and increased phosphorylation of CRE binding protein (CREB) and NPY mRNA levels in the Arc.

It is well established that fasting decreases circulating insulin and leptin, two well known anorexigenic signals (Ahima et al., 1996; Ahren et al., 1997). These changes might be responsible for the regulation of CRE-mediated gene expression because leptin receptors are highly expressed in the Arc (Mercer et al., 1996; Elmquist et al., 1998; Håkansson et al., 1998) and leptin downregulates NPY gene expression and upregulates POMC gene expression (Schwartz et al., 1996; Thornton et al., 1997; Wang et al., 1997; Mizuno et al., 1998). The long leptin receptor isoform found specifically in the hypothalamus bears homology to the signaling subunits of the cytokine receptor family and can activate the Janus kinase (JAK) family, causing rapid phosphorylation of signal transducers and activators of transcription (STATs) (Baumann et al., 1996; Ghilardi et al., 1996). However, the involvement of the JAKSTAT signaling pathway in leptin-induced regulation of hypothalamic neuropeptide gene expression has not been determined. This study was designed to investigate whether leptin modulates CRE-mediated gene transcription induced during 
fasting. We demonstrate here that leptin downregulates fasting-stimulated CRE-mediated gene induction and NPY gene induction in the Arc, providing evidence that leptin may regulate hypothalamic gene expression by modifying CREmediated transactivation.

\section{Materials and Methods}

Animals. Mice containing an insertion of a CRE-lacZ construct were obtained from Drs. S. Impey and D. Storm (Impey et al., 1996). The construct contained six tandem CREs upstream from a minimal Rous sarcoma virus promoter that drives the expression of $\beta$-galactosidase. Physiological relevance of a reporter gene expression in CRE-lacZ mice has been demonstrated both in vivo and in vitro (Impey et al., 1996; Obrietan et al., 1999). Mice were bred by mating a male transgenic heterozygous animal with a C57BL/6J wild-type female obtained from a commercial vendor and were genotyped by PCR for lacZ. The mice were maintained on a $12 \mathrm{hr}$ light/dark schedule with lights on at 6:00 A.M. and unlimited access to food and water. All animal use procedures were in strict accordance with institutional guidelines for the Care and Use of Laboratory Animals at the University of Washington (Seattle, WA). Male mice aged 10-14 weeks were assigned to control or fasting groups when their weights reached $24.0-29.0 \mathrm{gm}$. At this time there were no significant differences in body weights between the two groups. The mice were fed ad libitum or fasted for 16-48 hr with free access to water. To assess effects of phosphodiesterase (PDE) inhibitors, mice were injected intraperitoneally with saline or either the PDE3-specific inhibitor milrinone or the PDE4-specific inhibitor rolipram $(1 \mathrm{mg} / \mathrm{kg}$ body weight, three times during a $48 \mathrm{hr}$ fast) (Calbiochem, La Jolla, CA) during fasting. The dosages of the PDE inhibitors were determined by previous animal studies (Wachtel, 1983; Sweet et al., 1988; O'Donnell and Frith, 1999). For treatment with leptin, recombinant murine leptin (PeproTech, Rocky Hill, NJ) was injected intraperitoneally $(2 \mathrm{mg} / \mathrm{kg}$ body weight, three times during a $48 \mathrm{hr}$ fast). The dosage of leptin used was based on previous studies in which leptin $\left(3-5 \mathrm{mg} \cdot \mathrm{kg}^{-1} \cdot \mathrm{d}^{-1}\right)$ was subchronically injected in mice (Ahima et al., 1996; Schwartz et al., 1996; Thornton et al., 1997; Mizuno and Mobbs, 1999). For experiments involving the injection into the medial basal hypothalamus (the area above the Arc), a 24 gauge stainless steel guide cannula was stereotaxically implanted unilaterally $0.3 \mathrm{~mm}$ above the dorsolateral border of the Arc. The stereotaxic coordinates were $1.6 \mathrm{~mm}$ posterior to the bregma, $0.4 \mathrm{~mm}$ lateral to the midsagittal sinus, and $5.3 \mathrm{~mm}$ ventral to the surface of the skull. The cannulas were permanently anchored to the skull with dental acrylic. To maintain patency, a 30 gauge stainless steel obturator was inserted into the lumen of each cannula. After animals were allowed at least $10 \mathrm{~d}$ of postoperative recovery, they were injected with the Rpisomer of 8-bromo-adenosine $3^{\prime}, 5^{\prime}$-cyclic monophosphorothioate (Rp8-Br-cAMPS; $4 \mathrm{nmol}$ dissolved in $0.3 \mu \mathrm{l}$ of saline) (Calbiochem) or saline and fasted for $48 \mathrm{hr}$. For intracerebroventricular injection of leptin, the stereotaxic coordinates were $0.5 \mathrm{~mm}$ posterior to the bregma, $1.6 \mathrm{~mm}$ lateral to the midsagittal sinus, and $2.4 \mathrm{~mm}$ ventral to the surface of the skull. Murine leptin $(2 \mu \mathrm{g})$ was injected three times during a $48 \mathrm{hr}$ fast.

Tissue preparation. Animals destined for immunocytochemistry were anesthetized with phenobarbital and perfused with heparin PBS and 4\% paraformaldehyde in $0.1 \mathrm{M}$ phosphate buffer, $\mathrm{pH}$ 7.4. After perfusion, brains were removed from the skull, and the posterior cerebrum was excised. The tissues were post-fixed overnight in the same $4 \%$ paraformaldehyde fixative and then cryoprotected by incubating with consecutive concentrations of sucrose $(10,20$, and $30 \%)$ in PBS buffer. All tissues were then frozen in OCT compound and stored at $-70^{\circ} \mathrm{C}$ until cryostat sectioning at $-20^{\circ} \mathrm{C}$. For in situ hybridization, animals were decapitated, and the posterior cerebrum was rapidly placed in $4 \%$ paraformaldehyde

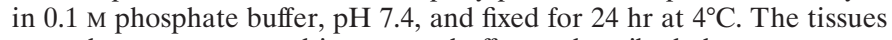
were then cryoprotected in sucrose buffer as described above.

Immunocytochemistry. A mouse brain atlas (Franklin and Paxinos, 1996) was used as a guide to match coronal brain sections across animals. The medial Arc area was anatomically distinguished by the appearance of median eminence and the elongation of the third ventricle (bregma $-1.3 \mathrm{~mm}$ to $-2.4 \mathrm{~mm}$ ). Each brain region was sectioned into a series of $7-10$ coronal sections containing the Arc (a 30- $\mu \mathrm{m}$-thick section from every $80-100 \mu \mathrm{m})$. Free-floating sections were preincubated in PBS containing $5 \%$ goat serum, $1 \mathrm{mg} / \mathrm{ml} \mathrm{BSA}$, and $0.05 \%$ Triton X-100 for 1 $\mathrm{hr}$ and incubated with anti- $\beta$-galactosidase antibody (1:500; 5'Prime 3'Prime, Boulder, CO) or anti-phosphorylated CREB antibody (1:500;
New England BioLabs, Beverly, MA) in PBS containing 1\% goat serum, $1 \mathrm{mg} / \mathrm{ml} \mathrm{BSA}$, and $0.05 \%$ Triton X-100 overnight at $4^{\circ} \mathrm{C}$ under continuous gentle agitation on a rotary shaker. All PBS solutions for labeling of phosphorylated CREB contained $\mathrm{NaF}(1 \mathrm{~mm})$. For detection of $\beta$-galactosidase immunoreactivity (IR), the sections were washed in PBS containing $0.05 \%$ Tween (three times for $20 \mathrm{~min}$ each), then incubated in goat anti-rabbit IgG conjugated to Alexa-Fluor 488 (1:500; Molecular Probes, Eugene, OR) for $2 \mathrm{hr}$ at room temperature. After additional washes in PBS, the sections were counterstained with propidium iodide. For amplification of phospho-CREB-IR, the sections were incubated with a goat anti-rabbit IgG biotin-conjugated antibody (1:400; Vector Laboratories, Burlingame, CA) for $2 \mathrm{hr}$ at room temperature, and antigen-antibody reactions were visualized using Vectastain ABC (Vector). Control and treatment groups were analyzed together under the same experimental conditions.

In situ hybridization. ${ }^{35}$ S-Labeled cRNA probes for N PY mRNA (a 527 bp fragment encoding entire mouse NPY subcloned from mouse EST 385331) and POMC mRNA (a 377 bp fragment encoding part of mouse POMC exon 3 subcloned from mouse EST 388641) were synthesized by in vitro transcription with T7 or SP6 polymerase (Stratagene, La Jolla, CA). A series of $8-10$ coronal sections (30 $\mu \mathrm{m}$ thick) containing the Arc (bregma $-1.3 \mathrm{~mm}$ to $-2.4 \mathrm{~mm}$ ) were cut through each brain as described above and saved in ice-cold PBS, $\mathrm{pH}$ 7.4. Free-floating sections were acetylated with tetraethylammonium and acetic anhydrate, prehybridized for $3 \mathrm{hr}$ at $60^{\circ} \mathrm{C}$, and hybridized for $16 \mathrm{hr}$ at $60^{\circ} \mathrm{C}$ using a probe concentration of $0.1 \mathrm{ng} \cdot \mu \mathrm{l}^{-1} \cdot \mathrm{Kb}^{-1}$ in the hybridization buffer (consisting of $50 \%$ deionized formamide, $10 \%$ dextran sulfate, $0.3 \mathrm{M} \mathrm{NaCl}$, $1 \times$ Denhardt's solution, $100 \mathrm{~mm}$ DTT, $1 \mathrm{~mm}$ EDTA, $1 \mathrm{mg} / \mathrm{ml}$ yeast tRNA, $100 \mu \mathrm{g} / \mathrm{ml}$ synthetic polyA RNA, and $10 \mathrm{~mm}$ Tris $\mathrm{HCl}, \mathrm{pH} 8.0$ ). The sections were treated with RNaseA at $37^{\circ} \mathrm{C}$ for $30 \mathrm{~min}$ and washed with $50 \%$ formamide containing $2 \times \mathrm{SSC}$ at $60^{\circ} \mathrm{C}$ for $30 \mathrm{~min}$ and $0.1 \times$ SSC at $60^{\circ} \mathrm{C}$ for $1 \mathrm{hr}$. Then the sections were mounted on slides, dried, and exposed to Kodak BioMax MR (Eastman Kodak, Rochester, NY) for 8-20 hr. Hybridization with sense probes for both NPY and POMC was included to confirm the specificity of the procedure and verify that background was at a negligible level.

Combination of immunocytochemistry with in situ hybridization. Freefloating sections from the fasted mice were first processed for immunocytochemical detection of $\beta$-galactosidase using the ABC method described above, except that all solutions were made with diethylpyrocarbonate-treated water. For visualization, the chromagen 3,3'-diaminobenzidine tetrahydrochloride (DAB) and hydrogen peroxide were used. Acetylation, prehybridization, and hybridization were performed as described above. The sections were mounted, dried, and dipped in NTB2 nuclear emulsion (Kodak). After a $2 \mathrm{~d}$ exposure, the slides were developed in D19 developer for $4 \mathrm{~min}$ at $15^{\circ} \mathrm{C}$ and fixed in rapid fixer for $5 \mathrm{~min}$.

Quantification of images. Analysis for $\beta$-galactosidase-IR was performed with MetaMorph software by measuring immunofluorescence signals from images taken on a Bio-Rad confocal microscope. Before a measurement was made, the background fluorescence intensity of each image was determined from the gray scale histogram ranging from 0 (black) to 255 (white). This value usually ranged from 63 to 73 . In most cases, the area of $\beta$-galactosidase-IR within the Arc was thresholded by the background value and marked with a red thresholding overlay as a visual indicator of the thresholded areas. Each pixel exceeding this threshold was counted, and the results were expressed as a percentage of the total pixels in the defined Arc area. The total Arc area was anatomically defined by propidium iodide counterstaining. In a few cases, the gray scale value of each thresholded pixel was determined and expressed as a percentage of the total gray scale pixel value in the defined Arc area. Essentially the same results were obtained. Phospho-CREB-IR images were taken by a positive $35 \mathrm{~mm}$ film and converted to computerized images. Percentages of threshold area were measured by MetaMorph software. Both $\beta$-galactosidase-IR and phospho-CREB-IR induced by fasting tended to accumulate more in the medial-caudal region of the Arc (bregma $-1.8 \mathrm{~mm}$ to $-2.4 \mathrm{~mm}$ ) than the rostral-medial region (bregma $-1.3 \mathrm{~mm}$ to $-1.8 \mathrm{~mm}$ ). The mean percentage threshold area for each animal, therefore, was obtained by computing the percentage threshold area of four to seven sections that showed a small variation $(<20 \%)$ within the Arc collected in the experiment (bregma $-1.3 \mathrm{~mm}$ to $-2.4 \mathrm{~mm}$ ). These means were used to calculate the overall mean \pm SEM for each group. Significant differences were determined using a twotailed unpaired Student's $t$ test or the Wilcoxon-Mann-Whitney test. For analysis of NPY and POMC mRNA levels, x-ray film exposures were 

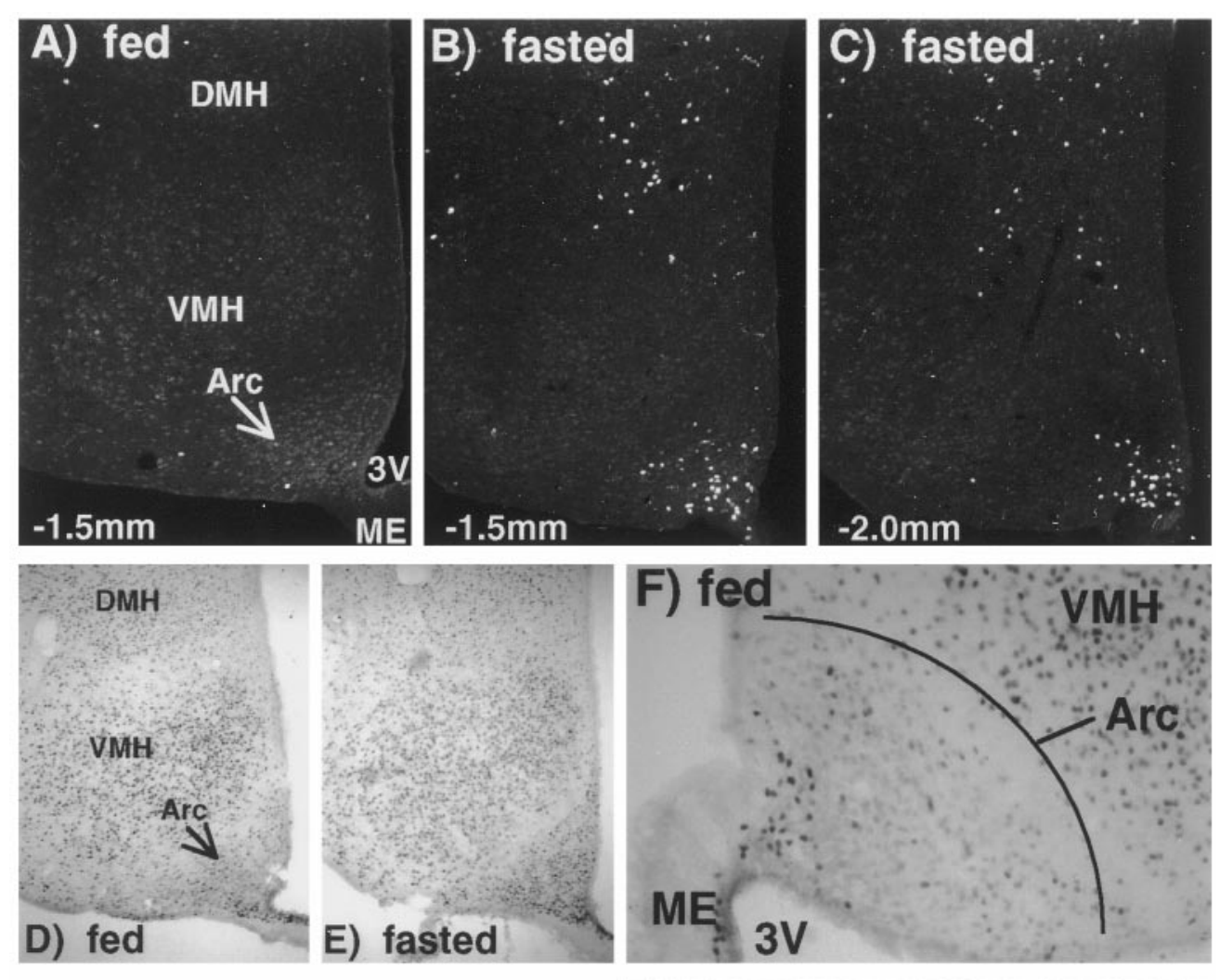

Figure 1. Immunocytochemical demonstration of fasting-induced CREmediated gene induction $(A-C)$ and CREB phosphorylation $(D-G)$ in the hypothalamus of CRE transgenic mice. Representative coronal sections through the hypothalamic region containing the arcuate nucleus (Arc) are shown. $\beta$-Galactosidase-IR in the Arc and the $\mathrm{DMH}$ were induced by fasting for $48 \mathrm{hr}$ $(B, C)$. Control animals fed ad libitum showed little or no $\beta$-galactosidase-IR $(A)$. The distance posterior to bregma, according to the mouse brain map described by Franklin and Paxinos (1996), is indicated in each coronal section. Fasting for $48 \mathrm{hr}$ increased CREB phosphorylation in the $\operatorname{Arc}(E, G)$. Control animals fed ad libitum showed only a weak basal phospho-CREB-IR in the $\operatorname{Arc}(D, F) . F$ and $G$ represent a higher magnification of phospho-CREB immunostaining in fed and fasted animals, respectively. Fasting-induced changes in $\beta$-galactosidase-IR and phosphoCREB-IR were quantified in the sections of the hypothalamic region containing the Arc of mice fasted for 16-48 hr as described in Materials and Methods $(H)$. The intensity of $\beta$-galactosidase-IR and phospho-CREB-IR for each fasting interval is plotted as the mean $( \pm$ SEM; $n=3-7$ animals per group) percentage of the maximal number observed for $\beta$-galactosidase-IR (48 hr) and phosphoCREB-IR (24 hr), respectively. $3 \mathrm{~V}$, Third ventricle; $M E$, median eminence; $D M H$, dorsomedial hypothalamic nucleus; $V M H$, ventromedial hypothalamic nucleus.
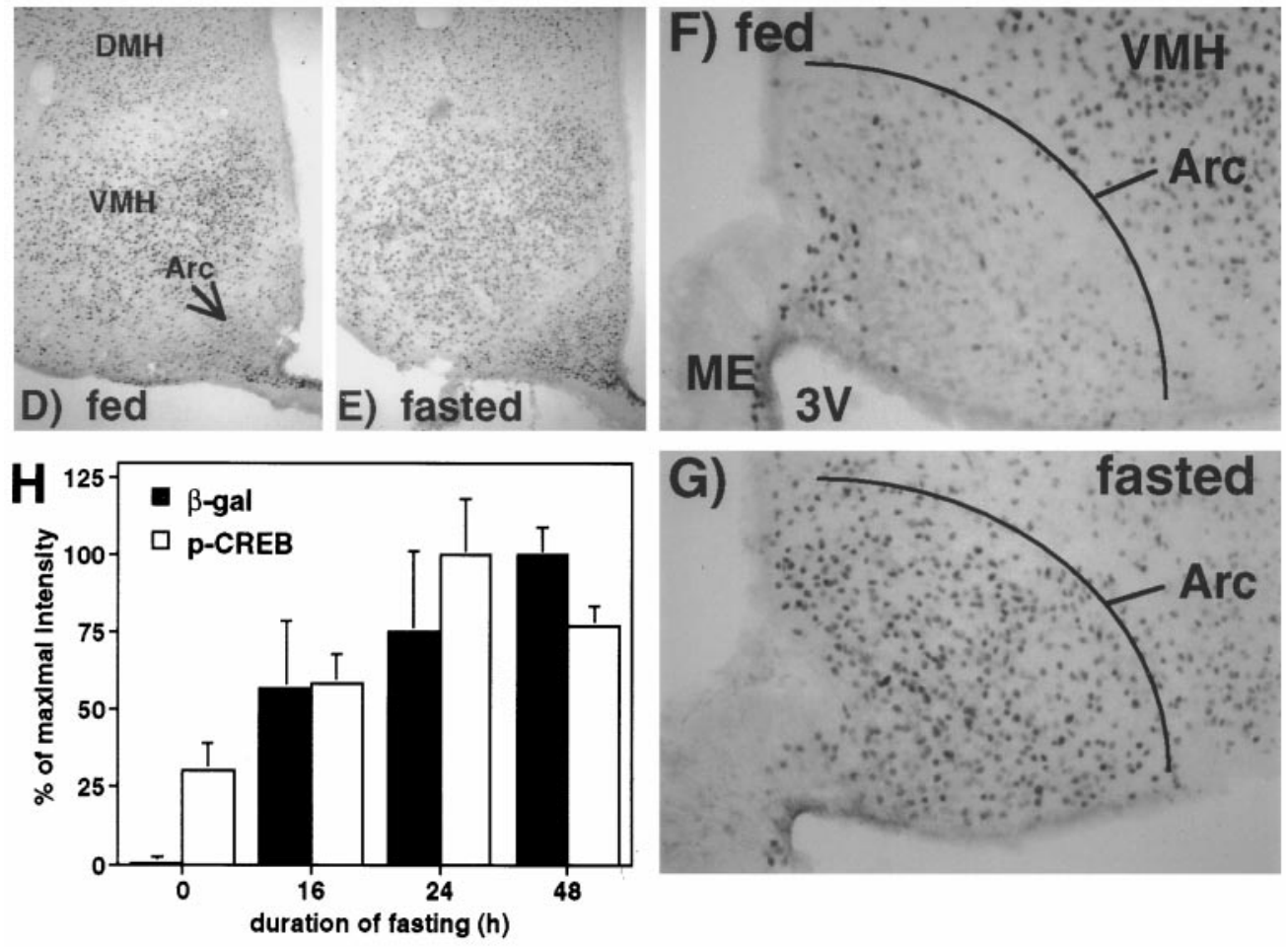

captured to a computer using a CCD camera (Sierra Scientific, Sunnyvale, CA), and relative levels of mRNA were measured by NIH image software. NPY and POMC mRNA levels were assessed by determining the total pixel area occupied on the film image by the hybridization signal from labeled cells within the Arc area. Pixel number in each animal was averaged from $8-10$ sections (bregma $-1.3 \mathrm{~mm}$ to $-2.4 \mathrm{~mm}$ ), and these averaged numbers were used to calculate the overall mean \pm SEM for each group. NPY mRNA signals tended to concentrate in the medialcaudal region of the Arc, whereas POMC mRNA signals were relatively highly distributed in the rostral-medial region of the Arc. The averaged number, therefore, provided the representative value of the mRNA level of each animal in the same Arc area rather than its maximal number. Significant differences between treatment groups were determined using either a two-tailed unpaired Student's $t$ test or one-way ANOVA, followed by Dunnett's multiple comparison test. A $p$ value of $<0.05$ was considered significant. To analyze colocalization of $\beta$-galactosidase-IR and NPY or POMC mRNA signals, NPY- or POMC-containing neurons were identified as a grain cluster if they exceeded background levels determined by scanning each section with dark-field optics. Under highpower, bright-field optics, if the grain cluster $(>10$ grains per cell) was verified as associating with DAB staining ( $\beta$-galactosidase-IR), this cell was counted as a $\beta$-galactosidase-expressing and NPY- or POMCcontaining neuron. The mean number of both $\beta$-galactosidase-IR and mRNA signal-expressing cells was computed for each animal (four to five sections of the intermediate aspect of the Arc of each animal), and these means were used to calculate the overall mean \pm SEM for each group.

\section{RESULTS}

\section{Activation of CRE-mediated gene induction by fasting in the mouse hypothalamus}

In the fed transgenic mice, the expression of the CRE reporter gene, $\beta$-galactosidase, was negligible in the hypothalamic area (Fig. $1 A$ ). After a $48 \mathrm{hr}$ fast, there was a significant increase in the number of positively labeled cells specifically in the Arc, and some labeled cells were observed in the dorsomedial hypothalamic nucleus $(\mathrm{DMH})$ (Fig. $1 B, C)$. A similar $\beta$-galactosidase expression pattern in the hypothalamus under fasting condition was seen in two independent breeder lines of the transgenic mice. Levels of CREB phosphorylation, the putative event preceding CRE-mediated gene expression, were also determined in the fasted animals by using a specific antibody for phosphorylated CREB (Fig. $1 D-G$ ). Fasting increased the intensity of phosphoCREB-IR in the area of the Arc (Fig. $1 F, G$ ). It is important to note that there was no difference in phospho-CREB-IR between 
control and fasting in the ventromedial hypothalamic nucleus (VMH), an adjacent area to the Arc, suggesting that the increased phosphorylation of CREB observed in the Arc is not artificial but a significant phenomenon. There was no change in the levels of phospho-CREB-IR in the DMH despite an increase in $\beta$-galactosidase expression caused by fasting in some cells. Quantification of both $\beta$-galactosidase-IR and phosphoCREB-IR of the Arc area indicated that the enhancement of the signals was dependent on the duration of fasting (16-48 hr). $\beta$-Galactosidase-IR showed a maximal increase under $48 \mathrm{hr}$ fasting, whereas the phospho-CREB level was higher after $24 \mathrm{hr}$ of fasting compared with $48 \mathrm{hr}$ (Fig. $1 H$ ). It is probable that fasting activated CRE-mediated gene induction by increasing phosphorylation of CREB in the Arc.

To determine whether PKA plays a significant role in fastinginduced CRE-mediated gene induction and CREB phosphorylation, the membrane-permeable PKA inhibitor Rp-8-Br-cAMPS $(4 \mathrm{nmol} / 0.3 \mu \mathrm{l})$ was injected into one side of the medial basal hypothalamus with the contralateral side serving as a control. Rp-8-Br-cAMPS significantly inhibited fasting-induced $\beta$-galactosidase expression by $74 \%$ on the injected side of the Arc compared with the uninjected contralateral side (Fig. 2A,C). Saline had no effect on $\beta$-galactosidase-IR in the injected side of the Arc (Fig. $2 B, C)(102 \%$ of the uninjected side), suggesting that the inhibitory effect of Rp-8-Br-cAMPS did not result from a damage of surrounding tissue by cannulation. Rp-8 Br-cAMPS also reduced the phospho-CREB-IR increased by fasting as compared with the uninjected side (Fig. 2D). Saline injection had no effect on the phospho-CREB-IR (Fig. 2E). It remains a possibility, however, that PKA inhibition in other hypothalamic regions may affect fasting-induced effects in the Arc because the drug is expected to diffuse to an area surrounding the Arc.

Moreover, we observed that intraperitoneal injection of PDE inhibitors milrinone ( $1 \mathrm{mg} / \mathrm{kg}$, three times during a $48 \mathrm{hr}$ fast) or rolipram ( $1 \mathrm{mg} / \mathrm{kg}$, three times during a $48 \mathrm{hr}$ fast) enhanced the fasting-induced $\beta$-galactosidase expression in the Arc by $53 \pm 9 \%$ (mean $\pm \mathrm{SEM}, n=4$ animals) and $65 \pm 11 \%(n=4)$, respectively, relative to intraperitoneal injection of saline (Fig. $3 D$ ). Figure $3 A-C$ shows typical images of $\beta$-galactosidase-IR in the Arc treated with saline, milrinone, or rolipram. The treatment of fed mice with the PDE inhibitors did not cause any significant changes in the $\beta$-galactosidase-IR at the dosage used.

\section{Changes in Arc NPY gene expression observed during fasting and effects of PDE inhibition}

Activation of Arc NPY neurons has been implicated as a strong stimulator of feeding. It has been reported consistently that a state of negative energy balance, such as fasting, upregulates NPY gene expression in the Arc, whereas it downregulates POMC gene expression (Bergendahl et al., 1992; Ahima et al., 1996; Mizuno et al., 1998). Consistent with these findings, we observed an increase in mRNA levels of NPY and a decrease in mRNA levels of POMC in the Arc of mice fasted for $48 \mathrm{hr}$ (Fig. $3 E$ ). If the stimulation of NPY gene expression by fasting requires CRE-mediated gene transactivation regulated by the CAMPPKA signaling pathway, it was expected that PDE inhibitors may modify the NPY mRNA levels during fasting. To test this hypothesis, the mice were injected intraperitoneally with milronine ( $1 \mathrm{mg} / \mathrm{kg}$, three times during a $48 \mathrm{hr}$ fast) or rolipram $(1 \mathrm{mg} / \mathrm{kg}$, three times during a $48 \mathrm{hr}$ fast) during $48 \mathrm{hr}$ fasting, and the NPY and POMC mRNA levels were analyzed. Consistent with our hypothesis, both PDE inhibitors significantly enhanced the
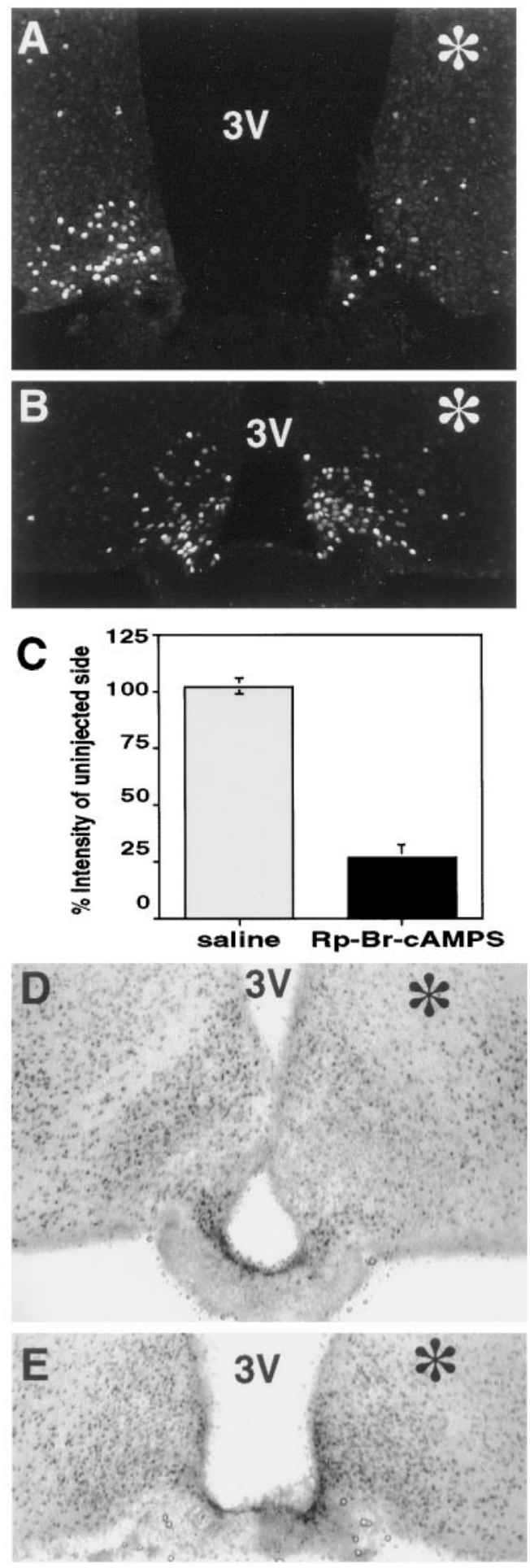

Figure 2. Effect of PKA inhibitor on fasting-induced CRE-mediated gene induction $(A)$ and phosphorylation of CREB $(D)$. A stainless steel guide cannula was stereotaxically implanted unilaterally in the medial basal hypothalamus $(0.3 \mathrm{~mm}$ above the dorsolateral border of the Arc; an asterisk indicates the hemisphere that was injected). Mice were injected with Rp-8Br-cAMPS (4 nmol dissolved in $0.3 \mu \mathrm{l}$ of saline) $(A, D)$ or saline $(B, E)$ and fasted for $48 \mathrm{hr}$. PKA inhibition attenuated fasting-induced $\beta$-galactosidase expression on the injection side of the Arc relative to the uninjected side $(A)$. The intensity of $\beta$-galactosidase-IR on the microinjected side is represented as a percentage of the mean ( \pm SEM; $n=4$ animals per group) $\beta$-galactosidase-IR on the uninjected side $(C)$. Rp-8-Br-cAMPS also attenuated the fasting-induced CREB phosphorylation on the injection side $(D)$. Saline injection had no effect on the levels of CREB phosphorylation $(E)$. 

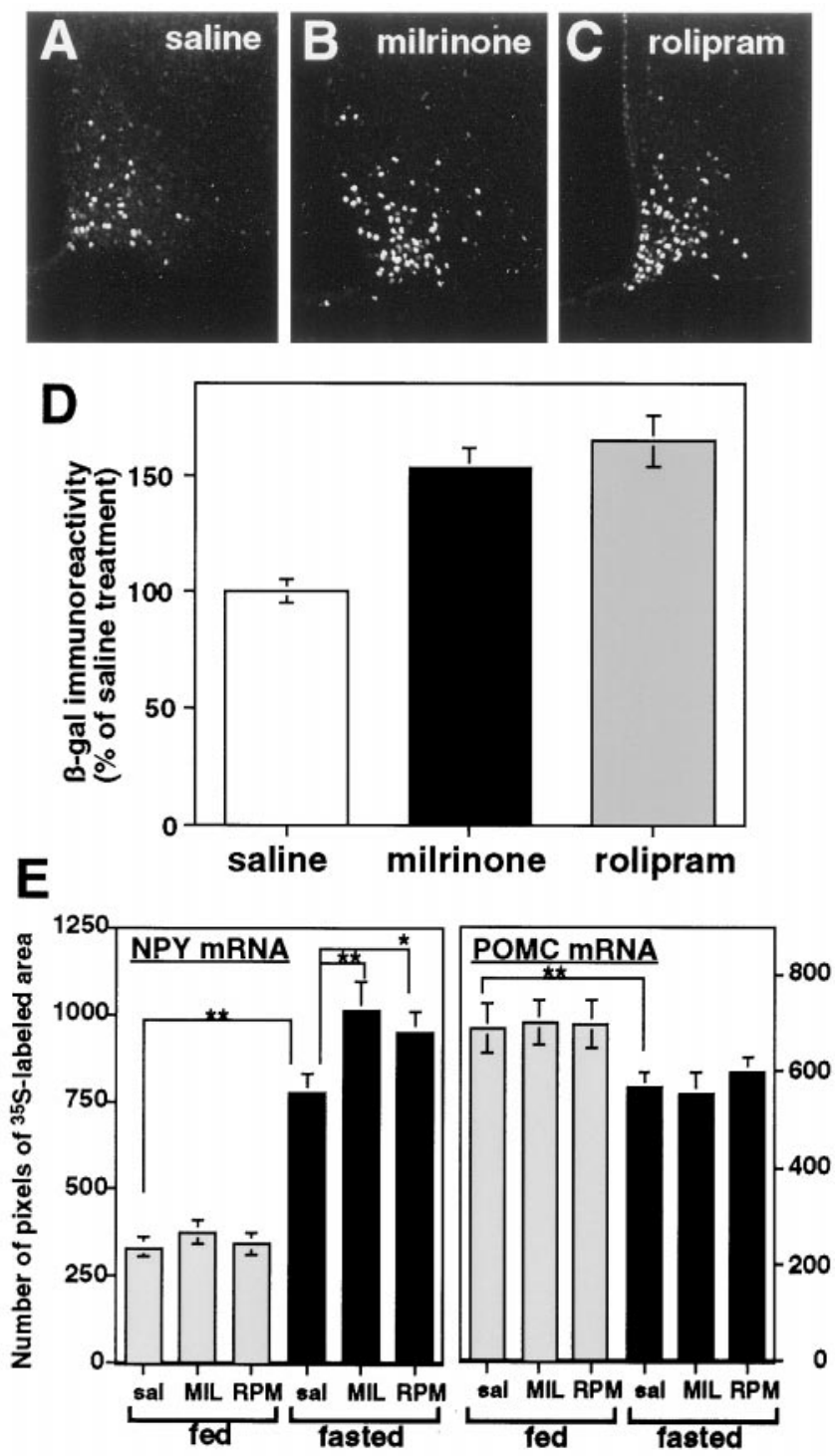

Figure 3. PDE inhibitors increased $\beta$-galactosidase and NPY mRNA expression in the Arc of the fasted mice. Mice were injected intraperitoneally with milrinone $(M I L)$, rolipram $(R P M)(1 \mathrm{mg} / \mathrm{kg}$ body weight, three times during a $48 \mathrm{hr}$ fast), or saline (sal). PDE inhibitors enhanced fasting-induced CRE-mediated gene expression in the Arc $(A-C)$. Levels of $\beta$-galactosidase-IR in milrinone- and rolipram-treated groups were increased by $53 \pm 9 \%$ (mean \pm SEM; $n=4$ animals) and $65 \pm 11 \%(n=$ $4)$, respectively, relative to saline treatment $(D)$. Neither milrinone nor rolipram had any effects on $\beta$-galactosidase-IR in mice fed ad libitum. $E$ represents the effects of PDE inhibitors on NPY and POMC mRNA levels in fed and fasted animals. Animals were treated as described above. In situ hybridization was performed using ${ }^{35}$ S-labeled cRNA probes for NPY and POMC and analyzed as described in Materials and Methods. Each value shows the mean ( \pm SEM; $n=3$ animals per group) number of pixels of ${ }^{35}$ S-labeled area. The data represent a typical result among three repeated experiments. ${ }^{*} p<0.05,{ }^{* *} p<0.01$.

fasting-induced increases in mRNA for NPY but not for POMC (Fig. 3E). Treatment with the PDE inhibitors had no effect on either NPY or POMC mRNA levels in fed animals.

\section{CRE-mediated gene induction in NPY neurons by fasting}

Fasting increased CRE-mediated gene induction and NPY mRNA levels in the Arc. Both changes were amplified by treatment with PDE inhibitors. A site resembling a CRE has been
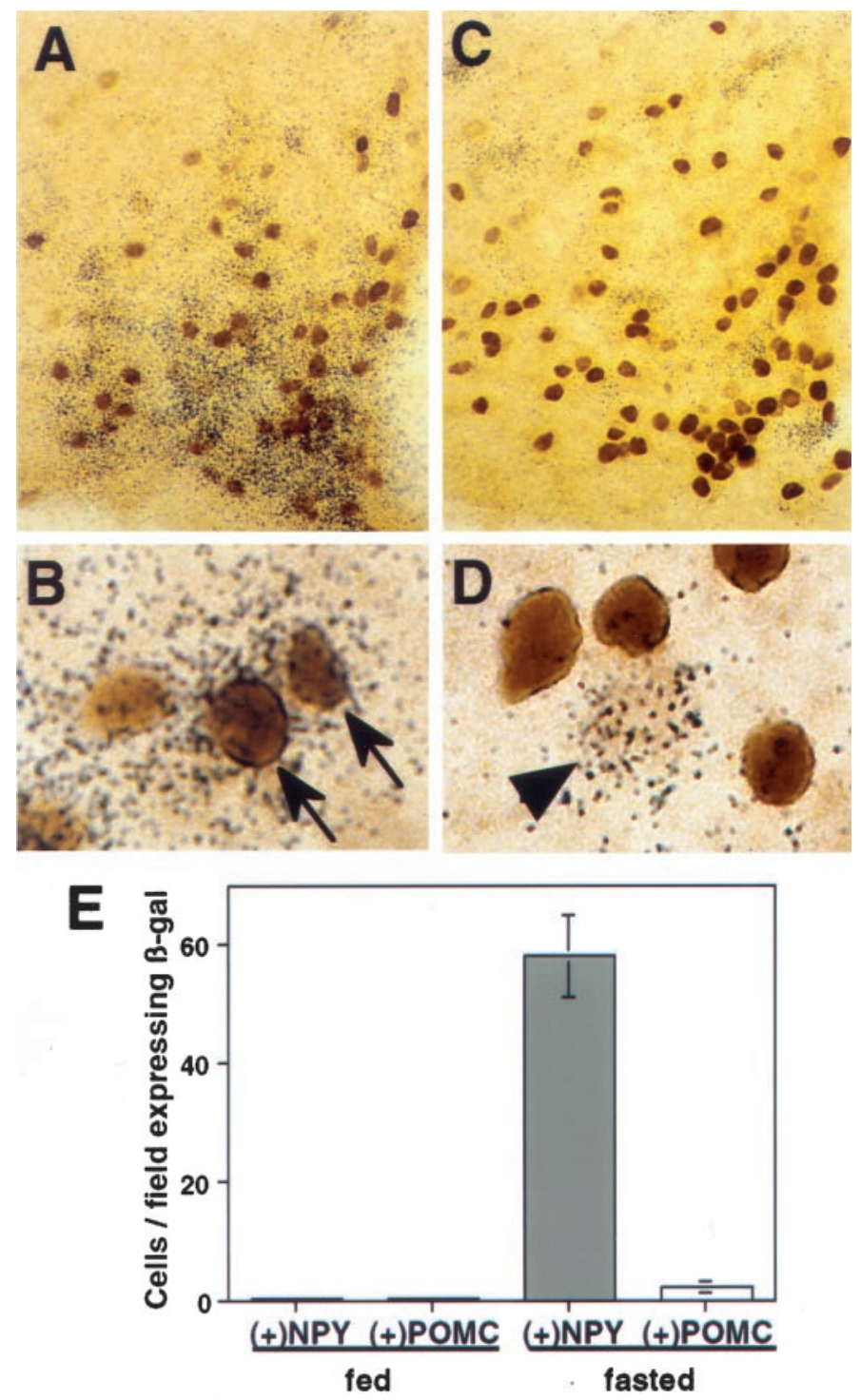

Figure 4. Fasting activates Arc NPY neurons. Photomicrographs of coronal Arc sections of mice fasted for $48 \mathrm{hr}$ were treated to detect $\beta$-galactosidase-IR (brown staining) and either NPY mRNA $(A, B)$ or POMC mRNA $(C, D)$ signals detected by autoradiographic grains. Highpower magnification photographs $(B, D)$ show colocalization of $\beta$-galactosidase-IR and NPY mRNA ( $B$, arrows) but not POMC mRNA $(D$, arrowhead). Graph illustrates the mean ( \pm SEM; $n=4$ animals per group) numbers of cells on one side of the Arc in which $\beta$-galactosidase expression colocalized with either NPY mRNA or POMC mRNA in mice fed ad libitum or fasted for $48 \mathrm{hr}(E)$. The total number of $\beta$-galactosidase-expressing cells on one side of the Arc is $61 \pm 6$ (mean \pm SEM; $n=4$ animals) and $2 \pm 1$ ( $n=4$ animals) in fasted and fed mice, respectively.

shown to exist on the promoter region of the rat NPY gene (Larhammar et al., 1987; Higuchi et al., 1988). Thus, fastinginduced CREB phosphorylation could conceivably enhance NPY gene levels through CRE transactivation in the Arc. To test this possibility, brain sections of fasted mice were double-labeled for NPY mRNA and $\beta$-galactosidase-IR (Fig. $4 A-D$ ). Figure $4 E$ depicts the number of cells expressing $\beta$-galactosidase in one side of the Arc that were colabeled with NPY or POMC radiolabeled cRNA probes. Ninety-seven percent of $\beta$-galactosidaseexpressing cells colocalized with NPY mRNA signals (Fig. $4 A, B)$, whereas $\beta$-galactosidase-expressing cells did not contain 


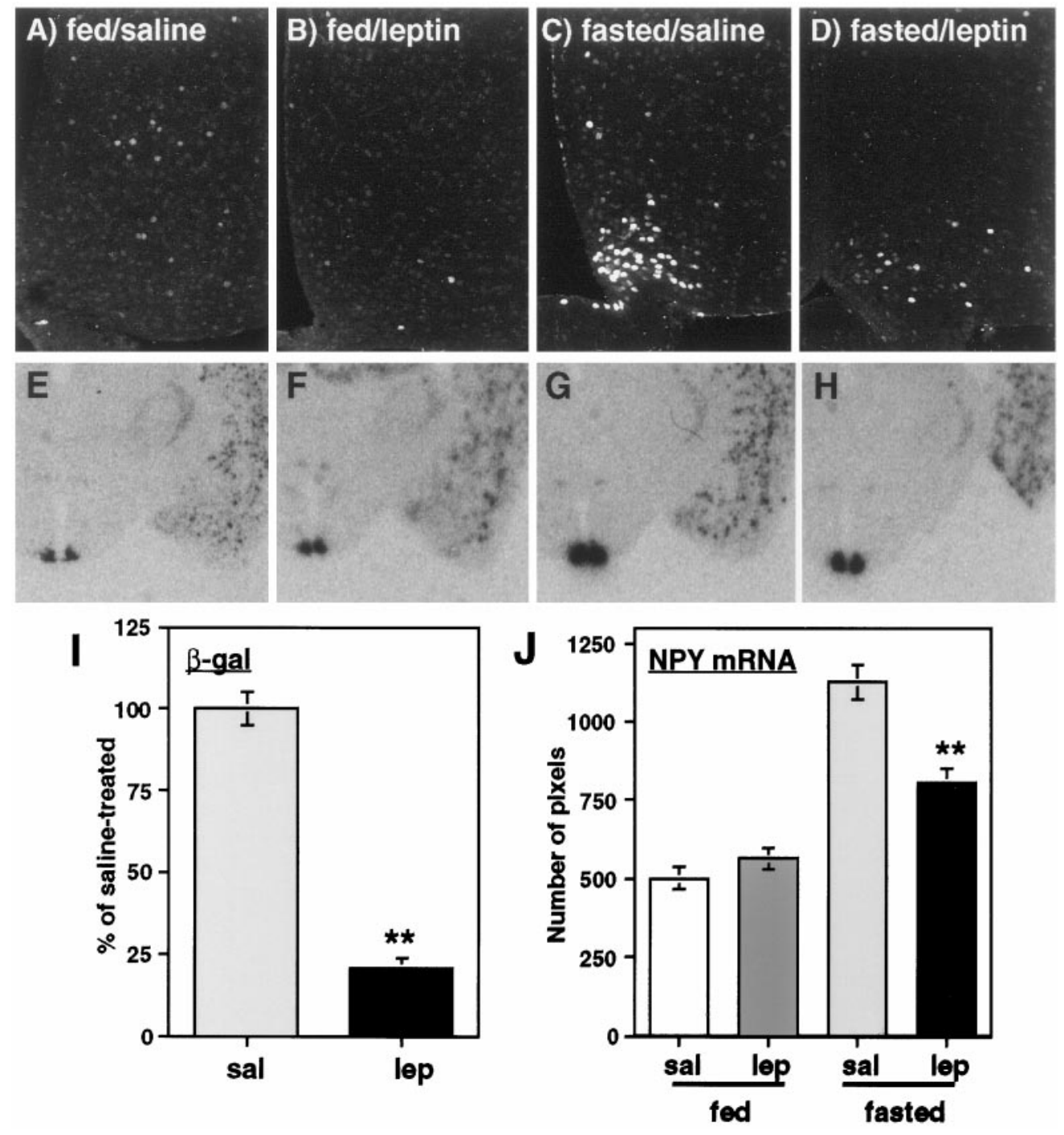

Figure 5. Leptin downregulates fasting-induced CRE-mediated gene expression and NPY gene induction. Expression of $\beta$-galactosidase $(A-D)$ and NPY mRNA $(E-H)$ in the Arc in fed or fasted mice treated with leptin (2 $\mathrm{mg} / \mathrm{kg}$ body weight, i.p., three times during a $42 \mathrm{hr}$ fast $)(B, D, F, H)$ or saline $(A, C, E, G)$. Mean intensity $( \pm$ SEM; $n=8$ animals for each treatment group) of $\beta$-galactosidase-IR in the Arc in fasted mice treated with either leptin or saline is plotted as a percentage of saline-treated controls $(I)$. Intensity of autoradiography is plotted as the number of pixels (mean \pm SEM; $n=3$ animals for each treatment group) labeled for NPY mRNA in the Arc of mice fed or fasted (42 hr) and treated with either saline or leptin $(J)$. Data represent a typical result among four repeated experiments. ${ }^{*} p<0.01$ relative to saline-treated controls.
POMC mRNA signals (Fig. 4C,D). The same analysis in milrinone-treated animals under fasting showed that enhancement of fasting-induced $\beta$-galactosidase expression by the PDE inhibitor occurred in NPY neurons but not POMC neurons (data not shown).

\section{Effects of leptin on fasting-induced increases of CRE- mediated gene induction and NPY mRNA expression}

Either central or peripheral administration of leptin has been reported to downregulate the expression of NPY genes under starvation (Wang et al., 1997; Mizuno and Mobbs, 1999). Immunocytochemical studies have shown that leptin receptors were localized in NPY and POMC neurons in the Arc (Mercer et al., 1996; Cheung et al., 1997; Baskin et al., 1999; Horvath et al., 1999). Therefore, we hypothesized that leptin might regulate NPY levels by modulating intracellular signaling to CRE. To assess this possibility, mice were injected intraperitoneally with leptin (2 $\mathrm{mg} / \mathrm{kg}$, three times during a $42 \mathrm{hr}$ fast), and $\beta$-galactosidase expression (Fig. $5 A-D$ ), and NPY mRNA levels (Fig. $5 E-H)$ of the Arc were qualitatively and quantitatively assessed. Peripheral administration of leptin attenuated the fasting-induced increases of $\beta$-galactosidase expression (Fig. $5 D, I$ ) and NPY mRNA levels (Fig. $5 H, J$ ). In fed mice, leptin did not have significant effects on either $\beta$-galactosidase expression or NPY mRNA levels (Fig. 5B, $F$ ).

To ascertain whether the effect of leptin on fasting-induced CRE-mediated gene induction was mediated by hypothalamic leptin receptors and not peripheral effects mediated by leptin, (e.g., effects on insulin secretion and fatty acid metabolism), leptin ( $2 \mu \mathrm{g}$, i.c.v., three times during a $48 \mathrm{hr}$ fast) was centrally administered during fasting. Central administration of leptin also inhibited fasting-induced CRE-mediated gene induction in the Arc [78 $\pm 6 \%$ mean inhibition of saline-injected control, ( \pm SEM), four animals per treatment group], suggesting that leptin-induced attenuation of fasting-induced CRE-mediated gene induction resulted from stimulation of hypothalamic leptin receptors. These data support a role for leptin in negative regulation of NPY gene expression as shown in previous reports and suggest that at least part of the mechanism of this effect is by downregulation of CRE-mediated gene induction stimulated by fasting in the Arc.

\section{DISCUSSION}

Our results show that fasting increases phosphorylation of CREB and stimulates CRE-mediated gene induction in the Arc. CREmediated gene expression induced by fasting was decreased by 
inhibition of PKA and enhanced by PDE inhibitors, suggesting that the cAMP-PKA signaling pathway is required in CREmediated gene expression during fasting. Our observation that fasting increased NPY mRNA expression in the Arc is consistent with previous reports showing that fasting augmented NPY gene expression in the Arc and increased NPY release to the paraventricular nucleus (PVN) (Kalra et al., 1991; Marks et al., 1992; Mizuno et al., 1998). The double-labeling experiments (Fig. 4) provided evidence that NPY neurons, but not POMC neurons, were activated during fasting and supported a possible role for CRE in stimulation of Arc NPY gene expression. Indeed, a site resembling a CRE has been shown to exist on the 5'-flanking region of the rat NPY gene (Larhammar et al., 1987; Higuchi et al., 1988). Several in vitro studies have also shown that NPY gene expression was activated by treatment with forskolin or cAMP analogs in PC12 cells, N18TG-2 neuroblastoma cells, and rat brain dissociated cells (Higuchi at al., 1988; Magni and Barnea, 1992). Moreover, an in vivo study recently reported that NPY protein levels were significantly increased in the Arc and the PVN when rats were intracerebroventricularly injected with dibutyrylcAMP (Akabayashi et al., 1994). Coupling these reports with the results of the present study, we conclude that CRE-mediated gene induction regulated by PKA is likely to be involved in increasing NPY gene expression in the Arc during starvation.

Leptin has been implicated in regulating feeding and energy expenditure (Campfield et al., 1995; Halaas et al., 1995, 1997; Ahima et al., 1996). During fasting, circulating leptin levels are markedly decreased, suggesting that decreased leptin may be interpreted at the level of the Arc as a cue to enhance CREmediated gene induction. The idea that NPY neurons may be one of the targets of leptin action has been supported by studies in which genetically obese $o b / o b$ and $d b / d b$ mice exhibited increased NPY mRNA in the Arc and NPY levels in various hypothalamic sites (Stephens et al., 1995; Schwartz et al., 1996; Woods et al., 1998). Furthermore, leptin receptors are expressed in NPY neurons in the Arc (Mercer et al., 1996; Baskin et al., 1999; Horvath et al., 1999). To examine whether CRE-mediated gene induction and NPY mRNA gene expression stimulated by fasting are a result of decreased circulating leptin levels, we administered leptin to fasted animals. The data showed that exogenously administered leptin attenuated both fasting-induced increases of $\beta$-galactosidase expression and NPY mRNA expression, suggesting that leptin modulates NPY gene levels by downregulation of CRE-mediated transactivation. However, because leptin did not completely counteract the fasting-induced effects, other physiological changes such as decreased insulin and/or glucose levels also might be involved in the regulation of gene induction during starvation.

Current evidence has strongly implicated increased NPY activity in the Arc as a key central mediator of hunger. Central administration of NPY stimulated feeding in both fasted and satiated animals (Clark et al., 1985), whereas immunoneutralization of NPY decreased food intake in rats (Dube et al., 1994) and selective antagonists of Y1 and Y5 receptors, which are highly expressed in the brain attenuated feeding (Kanatani et al., 1996; Schaff hauser et al., 1997). These support the idea that leptin plays a key physiological role in controlling food intake by regulating the NPY gene. However, NPY neurons contain agouti-related transcripts that also produce orexigenic effects by inhibiting melanocortin receptors (Ollmann et al., 1997; Shutter et al., 1997; Broberger et al., 1998: Hahn et al., 1998), and the mRNA levels of this transcript are increased under starvation and decreased by leptin (Mizuno and Mobbs, 1999). Therefore, it remains a possibility that agouti-related transcripts or another unknown molecule expressed in NPY neurons, or both, also might be regulated by CRE under starvation and may be targets of leptin.

What is the basis of leptin-induced downregulation of CREmediated gene induction? Sheriff et al. (1997) reported that fasting for $48 \mathrm{hr}$ increased phospho-CREB levels in nuclear extracts from the rat hypothalamus, an effect reversed by refeeding. These results suggest that decreased CREB phosphorylation and increased CREB dephosphorylation, or both, may negatively modulate gene expression responsible for the initiation of feeding. One of the possible cellular mechanisms of the negative regulation of leptin on CRE-mediated gene induction might be an attenuation of CREB phosphorylation. We have reported previously that leptin can decrease cAMP levels by the activation of a specific PDE isoform, PDE3B, thereby inhibiting insulin secretion stimulated by glucagon-like peptide- 1 in pancreatic $\beta$ cells (Zhao et al., 1998) and inducing insulin-like signaling in primary hepatocytes through activation of phosphatidylinositol 3-kinase and protein kinase B (Zhao et al., 2000). Our immunocytochemical study also showed that PDE3B is highly expressed in the mouse hypothalamus (data not shown). Therefore, leptin may negatively regulate cAMP levels through activation of PDE in the brain as well as $\beta$ cells, thereby attenuating phosphorylation of CREB. The precise molecular point of cross-talk between leptin and cAMP signal transduction in the brain, however, remains to be elucidated. Attenuation of CREB phosphorylation by leptin may depend on the modulating activity of a protein phosphatase. Morishita and colleagues (1998) showed that central injection of leptin in rats increased hypothalamic gene expression of protein phosphatase type 2B, [an enzyme implicated in the dephosphorylation of CREB (Enslen et al., 1994)].

Studies in cells transfected with leptin receptors showed that leptin stimulated JAK2 activity and phosphorylation of STATs, suggesting a role for the JAK-STAT signaling pathway downstream of the leptin receptor (Baumann et al., 1996; Ghilardi et al., 1996; Bjørbæk et al., 1997). Recent in vivo studies demonstrated that peripheral administration of leptin specifically increased STAT3 tyrosine phosphorylation in the hypothalamus (Vaisse et al., 1996; McCowen et al., 1998) and increased mRNA expression of suppressors of cytokine signaling-3 (SOCS-3) induced by the activation of the JAK-STAT signaling pathway (Bjørbæk et al., 1998). The increase of CRE binding activity as well as the increased CREB phosphorylation in hypothalamic nuclear extracts of fasted mice has also been reported by Sheriff et al. (1997), suggesting that CREB-CRE binding may be regulated by other gene transcription factors such as STATs under conditions requiring different energy demands. The decreased circulating leptin levels observed during fasting may enhance CRE binding activity caused by released suppression of the STATs, resulting in an increase in CRE-mediated transcription. This idea may be supported by recent evidence showing that the STAT motif plays a role in cell type-specific transcription of the vasoactive intestinal peptide gene regulated by CRE (Hahm and Eiden, 1998) and that transcriptional regulation in the junB and interferon regulatory factor- 1 genes is uniquely accomplished by both a CRE-like site and a STAT-binding site in the interferon-6 response element (Kojima et al., 1996; Ichiba et al., 1998).

Another possible mechanism of leptin-induced downregulation on CRE-mediated gene induction may be attributable to an indirect regulation of NPY neurons by leptin through other neuronal groups. Arc POMC neurons express leptin receptors 
(Cheung et al., 1997; Håkansson et al., 1998), and POMC and NPY neurons are synaptically linked in the Arc (Horvath et al., 1992; Broberger et al., 1997). Thus, gene expression in NPY neurons may be antagonistically modulated by POMC neurons during fasting and leptin treatment. Our results suggest that fasting does not elicit CRE-mediated gene induction in POMC neurons, although the POMC gene contains a motif resembling a CRE on its promoter (Kraus and Höllt, 1995), suggesting the existence of separate transcriptional pathways that regulate CREmediated gene induction in discrete neuronal populations. Indeed, Elias et al. (1999) has recently demonstrated that leptin induced SOCS-3 mRNA expression in both NPY and POMC neurons but Fos expression in only POMC neurons. It is also conceivable that leptin may act on other hypothalamic nuclear groups, such as the $\mathrm{DMH}$ and the $\mathrm{VMH}$ that were found to be directly activated by leptin using the c-fos method (Elmquist et al., 1997). Leptin has been reported to inhibit the depolarizationinduced release of noradrenaline and dopamine from isolated hypothalamic neuronal endings (Brunetti et al., 1999), suggesting a possibility that leptin may modulate the activity of presynaptic neurons that innervate Arc NPY neurons.

The study presented here provides the first evidence that activation of Arc NPY neurons but not POMC neurons results in stimulation of CRE-mediated gene induction during fasting. Fasting-stimulated CRE-mediated gene induction in NPY neurons requires $\mathrm{CREB}$ phosphorylation and activation, at least partly, by PKA. More importantly, administration of leptin downregulated fasting-induced CRE-mediated gene induction and NPY mRNA levels in the Arc. These results suggest that CREB$\mathrm{CRE}$ is one of the important molecular loci associated with the regulatory effects of leptin on hypothalamic gene expression in NPY neurons. Downregulation of CRE-mediated gene induction may be an important component in the molecular mechanism underlying the central effect of leptin on regulating feeding behavior.

\section{REFERENCES}

Ahima RS, Prabakaran D, Mantzoros C, Qu D, Lowell B, Maratos-Flier E, Flier JS (1996) Role of leptin in the neuroendocrine response to fasting. Nature 382:250-252.

Ahren B, Mansson S, Gingerich RL, Havel PJ (1997) Regulation of plasma leptin in mice: influence of age, high-fat diet, and fasting. Am J Physiol 273:R113-120.

Akabayashi A, Zaia CT, Gabriel SM, Silva I, Cheung WK, Leibowitz SF (1994) Intracerebroventricular injection of dibutyryl cyclic adenosine 3',5'-monophosphate increases hypothalamic levels of neuropeptide Y. Brain Res 660:323-328.

Baskin DG, Schwartz MW, Seeley RJ, Woods SC, Porte D, Breininger JF, Jonak Z, Schaefer J, Krouse M, Burghardt C, Campfield LA, Burn P, Kochan JP (1999) Leptin receptor long-form splice-variant protein expression in neuron cell bodies of the brain and co-localization with neuropeptide Y mRNA in the arcuate nucleus. J Histochem Cytochem 47:353-362.

Baumann H, Morella KK, White DW, Dembski M, Bailon PS, Kim H, Lai CF, Tartaglia LA (1996) The full-length leptin receptor has signaling capabilities of interleukin 6-type cytokine receptors. Proc Natl Acad Sci USA 93:8374-8378.

Bergendahl M, Wiemann JN, Clifton DK, Huhtaniemi I, Steiner RA (1992) Short-term starvation decreases POMC mRNA but does not alter GnRH mRNA in the brain of adult male rats. Neuroendocrinology 56:913-920.

Bjørbæk C, Uotani S, Silva B, Flier JS (1997) Divergent signaling capacities of the long and short isoforms of the leptin receptor. J Biol Chem 272:32689-32695.

Bjørbæk C, Elmquist JK, Frantz JD, Shoelson SE, Flier JS (1998) Identification of SOCS-3 as a potential mediator of central leptin resistance. Mol Cell 1:619-625.

Broberger C, Landry M, Wong H, Walsh J, Hokfelt T (1997) Subtypes $\mathrm{Y} 1$ and $\mathrm{Y} 2$ of the neuropeptide $\mathrm{Y}$ receptor are respectively expressed in pro-opiomelanocortin- and neuropeptide-Y-containing neurons of the rat hypothalamic arcuate nucleus. Neuroendocrinology 66:393-408.
Broberger C, Johansen J, Johansson C, Schalling M, Hokfelt T (1998) The neuropeptide Y/agouti gene-related protein (AGRP) brain circuitry in normal, anorectic, and monosodium glutamate-treated mice. Proc Natl Acad Sci USA 95:15043-15048.

Brunetti L, Michelotto B, Orlando G, Vacca M (1999) Leptin inhibits norepinephrine and dopamine release from rat hypothalamic neuronal endings. Eur J Pharmacol 372:237-240.

Campfield LA, Smith FJ, Guisez Y, Devos R, Burn P (1995) Recombinant mouse $\mathrm{OB}$ protein: evidence for a peripheral signal linking adiposity and central neural networks. Science 269:546-549.

Cheung CC, Clifton DK, Steiner RA (1997) Proopiomelanocortin neurons are direct targets for leptin in the hypothalamus. Endocrinology 138:4489-4492.

Clark JT, Kalra PS, Kalra SP (1985) Neuropeptide Y stimulates feeding but inhibits sexual behavior in rats. Endocrinology 117:2435-2442.

Dube MG, Xu B, Crowley WR, Kalra PS, Kalra SP (1994) Evidence that neuropeptide $\mathrm{Y}$ is a physiological signal for normal food intake. Brain Res 646:341-344.

Elias CF, Aschlkenasi C, Lee C, Kelly J, Ahima RS, Bjorbæk C, Flier JS, Saper CB, Elmquist JK (1999) Leptin differentially regulates NPY and POMC neurons projecting to the lateral hypothalamic area. Neuron 23:775-786.

Elmquist JK, Ahima RS, Maratos-Flier E, Flier JS, Saper CB (1997) Leptin activates neurons in ventrobasal hypothalamus and brainstem. Endocrinology 138:839-842.

Elmquist JK, Bjorbaek C, Ahima RS, Flier JS, Saper CB (1998) Distributions of leptin receptor mRNA isoforms in the rat brain. J Comp Neurol 395:535-547.

Enslen H, Sun P, Brickey D, Soderling SH, Klamo E, Soderling TR (1994) Characterization of $\mathrm{Ca}^{2+} /$ calmodulin-dependent protein $\mathrm{ki}$ nase IV: role in transcriptional regulation. $\mathrm{J}$ Biol Chem 269:15520-15527.

Franklin KBJ, Paxinos G (1996) The mouse brain in stereotaxic coordinates. San Diego: Academic.

Ghilardi N, Ziegler S, Wiestner A, Stoffel R, Heim MH, Skoda RC (1996) Defective STAT signaling by the leptin receptor in diabetic mice. Proc Natl Acad Sci USA 93:6231-6235.

Habener JF, Miller CP, Vallejo M (1995) cAMP-dependent regulation of gene transcription by cAMP response element-binding protein and cAMP response element modulator. Vitam Horm 51:1-57.

Hahm SH, Eiden LE (1998) Five discrete Cis-active domains direct cell type-specific transcripton of the vasoactive intestinal peptide (VIP) gene. J Biol Chem 273:17089-17094.

Hahn TM, Breininger JF, Baskin DG, Schwartz MW (1998) Coexpression of Agrp and NPY in fasting-activated hypothalamic neurons. Nat Neurosci 1:271-272.

Håkansson ML, Brown H, Ghilardi N, Skoda RC, Meister B (1998) Leptin receptor immunoreactivity in chemically defined target neurons of the hypothalamus. J Neurosci 18:559-572.

Halaas JL, Gajiwala KS, Maffei M, Cohen SL, Chait BT, Rabinowitz D, Lallone RL, Burley SK, Friedman JM (1995) Weight-reducing effects of the plasma protein encoded by the obese gene. Science 269:543-546.

Halaas JL, Boozer C, Blair-West J, Fidahusein N, Denton DA, Friedman JM (1997) Physiological response to long-term peripheral and central leptin infusion in lean and obese mice. Proc Natl Acad Sci USA 94:8878-8883.

Higuchi H, Yang HYT, Sabol SL (1988) Rat neuropeptide Y precursor gene expression: mRNA structure, tissue distribution, and regulation by glucocorticoids, cyclic AMP, and phorbol ester. J Biol Chem 263:6288-6295.

Horvath TL, Naftolin F, Kalra SP, Leranth C (1992) Neuropeptide Y innervation of $\beta$-endorphin-containing cells in the rat mediobasal hypothalamus: a light and electron microscopic double immunostaining analysis. 131:2461-2467.

Horvath TL, Diano S, van den Pol AN (1999) Synaptic interaction between hypocretin (orexin) and neuropeptide $\mathrm{Y}$ cells in the rodent and primate hypothalamus: a novel circuit implicated in metabolic and endocrine regulations. J Neurosci 19:1072-1087.

Ichiba M, Nakajima K, Yamanaka Y, Kiuchi N, Hirano T (1998) Autoregulation of the Stat3 gene through cooperation with a cAMPresponse element-binding protein. J Biol Chem 273:6132-6138.

Impey S, Mark M, Villacres EC, Poser S, Chavkin C, Storm DR (1996) Induction of CRE-mediated gene expression by stimuli that genetate long-lasting LTP in area CA1 of the hippocampus. Neuron 16:973-982.

Kalra SP, Dube MG, Sahu A, Phelps CP, Kalra PS (1991) Neuropeptide $Y$ secretion increases in the paraventricular nucleus in association with increased appetite for food. Proc Natl Acad Sci USA 88:10931-10935.

Kanatani A, Ishihara A, Asahi S, Tanaka T, Ozaki S, Ihara M (1996) Potent neuropeptide Y Y1 receptor antagonist, 1229U91: blockade of neuropeptide $\mathrm{Y}$-induced and physiological food intake. Endocrinology 137:3177-3182

Kim EM, Welch CC, Grace MK, Billington CJ, Levine AS (1996) Chronic food restriction and acute food deprivation decrease mRNA levels of opioid peptides in arcuate nucleus. Am J Physiol 270:R1019-1024. 
Kojima H, Nakajima K, Hirano T (1996) IL-6-inducible complexes on an IL-6 response element of the junB promoter contain Stat3 and 36 $\mathrm{kDa}$ CRE-like site binding protein(s). Oncogene 12:547-554.

Kraus J, Höllt V (1995) Identification of a cAMP-response element on the human proopiomelanocortin gene upstream promoter. DNA Cell Biol 14:103-110.

Larhammar D, Ericsson A, Persson H (1987) Structure and expression of the rat neuropeptide Y gene. Proc Natl Acad Sci USA 84:2068-2072.

Magni P, Barnea A (1992) Forskolin and phorbol ester stimulation of neuropeptide Y (NPY) production and secretion by aggregating fetal brain cells in culture: evidence for regulation of NPY biosynthesis at transcriptional and posttranscriptional levels. Endocrinology 130:976-984.

Marks JL, Li M, Schwartz MW, Porte DJ, Baskin DG (1992) Effect of fasting on regional levels of neuropeptide Y mRNA and insulin receptors in the rat hypothalamus: an autoradiographic study. Mol Cell Neurosci 3:199-205.

McCowen KC, Chow JC, Smith RJ (1998) Leptin signaling in the hypothalamus of normal rats in vivo. Endocrinology 139:4442-4447.

Mercer JG, Hoggard N, Williams LM, Lawrence CB, Hannah LT, Morgan PJ, Trayhum P (1996) Coexpression of leptin receptor and preproneuropeptide Y mRNA in arcuate nucleus of mouse hypothalamus. J Neuroendocrinol 8:733-735.

Mizuno TM, Mobbs CV (1999) Hypothalamic agouti-related protein messenger ribonucleic acid is inhibited by leptin and stimulated by fasting. Endocrinology 140:814-817.

Mizuno TM, Kleopoulos SP, Bergen HT, Roberts JL, Priest CA, Mobbs CV (1998) Hypothalamic pro-opiomelanocortin mRNA is reduced by fasting in ob/ob and $\mathrm{db} / \mathrm{db}$ mice, but is stimulated by leptin. Diabetes 47:294-297.

Morishita T, Hidaka T, Suguhara K, Noguchi T (1998) Leptin changes $\mathrm{Ca}^{2+} /$ calmodulin-dependent response and upregulates the gene expression of calcineurin in rat hypothalamus. Life Sci 63:311-315.

Obrietan K, Impey S, Smith D, Athos J, Storm DR (1999) Circadian regulation of CAMP response element-mediated gene expression in the suprachiasmatic nuclei. J Biol Chem 274:17748-17756.

O'Donnell JM, Frith S (1999) Behavioral effects of family-selective inhibitors of cyclic nucleotide phosphodiesterases. Pharmacol Biochem Behav 63:185-192.

Ollmann MM, Wilson BD, Yang YK, Kerns JA, Chen Y, Gantz I, Barsh GS (1997) Antagonism of central melanocortin receptors in vitro and in vivo by agouti-related protein. Science 278:135-138.

Schaffhauser AO, Stricker-Krongrad A, Brunner L, Cumin F, Gerald C, Whitebread S, Criscione L, Hofbauer KG (1997) Inhibition of food intake by neuropeptide Y Y5 receptor antisense oligodeoxyuncleotides. Diabetes 46:1792-1798.
Schwartz MW, Baskin DG, Bukowski TR, Kuijper JL, Foster D, Lasser G, Prunkard DE, Porte D, Woods SC, Seeley RJ, Weigle DS (1996a) Specificity of leptin action in elevated blood glucose levels and hypothalamic neuropeptide $\mathrm{Y}$ gene expression in ob/ob mice. Diabetes 45:531-535.

Sheriff S, Chance WT, Fischer JE, Balasubramaniam A (1997) Neuropeptide $Y$ treatment and food deprivation increase cyclic AMP response element-binding in rat hypothalamus. Mol Pharmacol 51:597-604.

Shutter JR, Graham M, Kinsey AC, Scully S, Luthy R, Stark KL (1997) Hypothalamic expression of ART, a novel gene related to agouti, is up-regulated in obese and diabetic mutant mice. Genes Dev 11:593-602.

Stephens TW, Basinski M, Bristow PK, Bue-Valleskey JM, Burgett SG, Craft L, Hale J, Hoffmann J, Hsiung HM, Kriauciunas A, MacKellar W, Rosteck Jr PR, Schoner B, Smith D, Tinsley FC, Zhang XY, Heiman M (1995) The role of neuropeptide $Y$ in the antiobesity action of the obese gene product. Nature 377:530-532.

Sweet CS, Ludden CT, Stabilito II, Emmert SE, Heyse JF (1988) Beneficial effects of milrinone and enalapril on long-term survival of rats with healed myocardial infarction. Eur J Pharmacol 147:29-37.

Thornton JE, Cheung CC, Clifton DK, Steiner RA (1997) Regulation of hypothalamic proopiomelanocortin mRNA by leptin in ob/ob mice. Endocrinology 138:5063-5066.

Vaisse C, Halaas JL, Horvath CM, Darnell JE, Stoffel M, Friedman JM (1996) Leptin activation of Stat3 in the hypothalamus of wild-type and $\mathrm{ob} / \mathrm{ob}$ mice but not db/db mice. Nat Genet 14:95-97.

Wachtel H (1983) Neurotropic effects of the optical isomers of the selective adenosine cyclic $3^{\prime}, 5^{\prime}$-monophosphate phosphodiesterase inhibitor rolipram in rats in-vivo. J Pharm Pharmacol 35:440-444.

Wang Q, Bing C, Al-Barazanji K, Mossakowaska DE, Wang XM, McBay DL, Neville WA, Taddayon M, Pickavance L, Dryden S, Thomas MEA, McHale MT, Gloyer IS, Wilson S, Buckingham R, Arch JRS, Trayhurn P, Williams G (1997) Interactions between leptin and hypothalamic neuropeptide $\mathrm{Y}$ neurons in the control of food intake and energy homeostasis in the rat. Diabetes 46:335-341.

Woods SC, Seeley RJ, Porte D, Schwartz MW (1998) Signals that regulate food intake and energy homeostasis. Science 280:1378-1383.

Zhao AZ, Bornfeldt KE, Beavo JA (1998) Leptin inhibits insulin secretion by activation of phosphodiesterase 3B. J Clin Invest 102:869-873. Zhao AZ, Shinohara MM, Huang D, Shimizu M, Eldar-Finkelman H, Krebs EG, Beavo JA, Bornfeldt KE (2000) Leptin induces insulin-like signaling that antagonizes cAMP elevation by glucagon in hepatocytes. J Biol Chem 275:11348-11354. 